\title{
Corporate Governance and Overproduction for State Owned and Privately Owned Companies
}

\author{
By
}

Ahmed Hany Behery

Professor of Accounting, faculty of commerce, Zagazig University

Mohamed Elsaeed Abulezz

Professor of Accounting, faculty of commerce, Zagazig University

Ahmed Boghdady Ahmed Boghdady

Assistant Lecturer, Accounting Department, Faculty of Commerce, Zagazig University 


\begin{abstract}
This study investigates the relationship between corporate governance mechanisms and earnings manipulation by overproduction in state owned compared with privately owned companies. Abnormal production cost (APROD) is used to measure overproduction practices. An empirical model is developed in which the abnormal production cost represents the dependent variable. The APROD model is tested using a sample of manufacturing companies containing state-owned and privately-owned companies over the period from 2010 to 2017, with 743 firm-year observations. The results show that the board size, board independence, number of audit committee meetings, and financial expertise for audit committee members appear effective mechanisms for curbing manipulation using production costs in state-owned manufacturing companies. For privately-owned manufacturing companies, the results reveal that only board independence and number of audit committee meetings appear effective mechanisms in constraining manipulation using production costs.
\end{abstract}

Keywords: Ownership type; corporate governance; real earnings management; overproduction. 


\section{Introduction}

Healy and Wahlen (1999) state that earnings management occurs when managerial judgment is used in financial reporting and in structuring operations to change financial reports either to mislead some stakeholders about the company's economic performance, or to influence contractual outcomes that depend on reported accounting figures. The earnings management practices are categorized as either the change in the accrual process (accrual earnings management (AEM)) or the deviation from normal business activity (real-activity earnings management (REM)).

Prior studies (e.g. Bushee, 1998; Degeorge et al., 1999; Roychowdhury, 2006) have provided several examples of REM that include offering discounts to accelerate sales from the next fiscal year into the current year, overproducing to decrease cost of goods sold and increase operating margins, delaying maintenance expenditure, research and development (R\&D), advertising and other discretionary SG \& A expenses to increase reported earnings, and selling fixed assets to affect gains and losses.

Prior research has primarily studied the role of corporate governance in the context of accruals management. However, Graham et al. (2005) document the pervasive occurrence of earnings management through real activities manipulation and note that managers are likely to prefer this type of earnings management in the post-Sarbanes-Oxley act era because much of the media and analysts' attention is focused on AEM. In contrast, the research focusing on REM has been scarce and is relatively recent. Nevertheless, there are mixed results related to the role of corporate governance mechanisms in mitigating REM. Some previous studies found that certain governance 
practices are important in limiting REM (e.g. Kang and Kim, 2012). Where others found that corporate governance mechanisms do not mitigate REM practiced by company management (e.g. Visvanathan, 2008).

Agency theory predicts that firms that are suffering from pronounced agency conflicts engage in opportunistic earnings management practices. agency problems are more likely to be more severe in state owned companies (SOEs) than in privately owned companies (POEs) due to the multiple types of conflicts of interest, including those between the state and minority shareholders and between the state and managers. The most important goal of the state may be political. For example, it is important to maintain employment levels or to control certain strategic industries (e.g. transportation) more than generating positive net profit or maximizing firm market value (Wu and Chen, 2006).

Despite the existence of many state-owned enterprises in Egypt, however, the majority of studies examining the phenomenon of earnings management concentrated on accrual earnings management and did not address SOEs separately to find out the extent to which SOEs differ from POEs in that respect due to the special nature of agency relationships and agency problems. Furthermore, most studies of state-owned companies in Egypt focused on the relationship between corporate governance and financial/operational performance or the impact of privatization on financial and /or operational performance. Consequently, investigation of corporate governance and real earnings management practices in the SOEs and comparing it with POEs is worthwhile and contributes to the existing literature, particularly when the evidence comes from a developing country such as Egypt. 
This study examines the moderating role of ownership type (i.e. stateowned vs. privately-owned) on the relationship between corporate governance and overproduction manipulation as a proxy for real earnings management practices. Consequently, the problem of this study can be summarized as follows:

Does ownership type (i.e. state ownership or private ownership) moderate the relationship between corporate governance mechanisms and real earnings management using overproduction?

\section{Literature Review and Hypotheses Development}

Despite the extensive evidence on the role of corporate governance mechanisms in limiting the AEM practices, a little research has questioned the role of corporate governance mechanisms in constraining REM (e.g. Visvanathan, 2008; Kang and Kim, 2011; Martinez, 2011; Kang and Kim, 2012). Furthermore, the results of such studies are mixed. Kang and Kim (2011) find that a well-established governance system can mitigate the REM practices. Using a sample of 6,759 firm-years, Visvanathan, (2008) examines the impact of several board and audit committee characteristics on REM. The results show only independent board members are influential in constraining REM, while the other characteristics of the board and the audit committee that have been found to be significant in limiting AEM have no effect in limiting REM, because most members may primarily focus upon accrual-type earnings management. However, Kang and Kim (2012) find that the board size in addition to the non-executive directors is negatively associated with REM. Similarly, Hashemi and Rabiee (2011) use 1,398 firm year observations and 
find that higher percentage of independent directors and larger board size appear to be more effective in terms of reducing REM.

Malik (2011) employs a sample of 7,852 fiscal quarters of publiclytraded U.S. firms and find that the board may not play any significant role to limit REM. Using 11,604 Chinese firm-year observations over the period 2002-2012, Hsu and Wen (2015) conclude that the board size and managerial ownership are negatively associated with REM while ownership concentration has a positive relationship with REM. The results show also the CEO duality and independent directors are ineffective in constraining REM practices. Regarding the financial expertise of audit committee members, Carcello et al. (2006) and Sun et al. (2014) find insignificant effect on REM.

In addition to the little number of studies examined the relationship between corporate governance mechanisms and REM, to the researcher's best knowledge, there is no study examined the moderation effect of ownership type on this relationship. Also, the prior research on the effect corporate governance on the REM, either in Egypt or in other environments, did not control for the possible substitutive effect between AEM and REM. In Egypt, to the researcher's best knowledge, no study examined the effect of corporate governance mechanisms in constraining the REM in both SOEs and POEs. Due to the inconsistent findings for the effect of corporate governance mechanisms on REM as well as the absence of any study examining this relationship in SOEs; the hypotheses can be formed in the null form as follows:

H1: There is no relationship between ownership type and overproduction. 
H2: The relationship between individual ownership concentration and overproduction does not depend on ownership type.

H3: The relationship between insider ownership and overproduction does not depend on ownership type.

H4: The relationship between board size and overproduction does not depend on ownership type.

H5: The relationship between board independence and overproduction does not depend on ownership type.

H6: The relationship between CEO duality and overproduction does not depend on ownership type.

H7: The relationship between audit committee size and overproduction does not depend on ownership type.

H8: The relationship between audit committee independence and overproduction does not depend on ownership type.

H9: The relationship between financial expertise of audit committee members and overproduction does not depend on ownership type.

H10: The relationship between the number of audit committee meetings and overproduction does not depend on ownership type.

\section{Methodology}

\subsection{Study Population and Sample}

A convenience sample of manufacturing companies comprising of stateowned and privately-owned companies over the period from 2010-2017, with 743 firm-year observations, is selected. All firms drawn from the population should have been registered in the security exchange market during the period $2010-2017$. 


\subsection{Empirical Research Models}

A regression model is developed to test the research hypotheses for one group sample containing state owned and privately owned Egyptian manufacturing companies listed in the Egyptian stock exchange for the period of 2010-2017. Abnormal production cost as a proxy for overproduction manipulation is regressed against ownership type, corporate governance mechanisms and control variables. Therefore, the empirical research modelcan be presented symbolically as follows,

The First Model:

$A P R O D_{i, t}=\beta_{0}+\beta_{1}$ OWNT $_{i, t}+\sum_{i=1}^{9} \theta C G M_{i, t}+\sum_{i=1}^{9} \propto$ OWNTi, $\times$ CGMi, $t+\beta_{2}$ PreEar $_{i, t}+$ $\sum_{i=1}^{10} \mu C T R L s_{i, t}$

$+$ $\varepsilon_{i, t}$

Where:

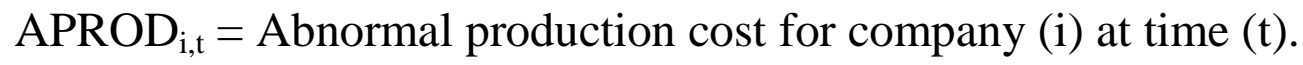

$\mathrm{OWNT}_{\mathrm{i}, \mathrm{t}}=$ ownership type.

$\mathrm{CGM}_{\mathrm{i}, \mathrm{t}} \quad=$ corporate governance mechanisms (individual ownership concentration, board size, board independence, CEO duality, audit committee size, audit committee independence, number of meetings and financial expertise for audit committee members).

PreEar $_{\mathrm{i}, \mathrm{t}}=$ pre-managed earnings.

CTRLs $_{i, t}=$ control variables (includes substitution control variables and firm characteristics variables).

$\propto, \theta, \mu, \beta=$ regression coefficients.

$\varepsilon_{i, t}=$ error. 


\subsection{Variables Measurement}

\subsubsection{Overproduction}

Managers may increase production more than the expected demand in order to reduce the cost per unit, lower reported cost of goods sold (COGS), increase operating margins and increase earnings. However, the company will still bear other production and holding costs that will result in higher annual production costs relative to sales, and lower cash flows from operations according to sales levels. Therefore, excessive production will lead to higher abnormal production costs (APROD). Roychowdhury (2006) develops a model to estimate the normal level of production cost, and defines the production cost as the sum of cost of goods sold (COGS) and change in inventory ( $\Delta$ INV) throughout the year. The normal level of COGS is estimated as a linear function of sales using the following cross-sectional regression.

$\operatorname{COGS}_{t} /$ TAA $_{t-1}=\beta_{1}\left(1 / T_{t-1}\right)+\beta_{2}\left(S_{t} / T_{t-1}\right)+\varepsilon_{t} \ldots \ldots \ldots \ldots \ldots \ldots \ldots \ldots \ldots(2)$

Where:

$\mathrm{COGS}_{\mathrm{t}}=$ cost of goods sold for period $\mathrm{t}$.

Next, the model for normal inventory is estimated as follows:

$\Delta \operatorname{INV}_{\mathrm{t}} / \mathbf{T A}_{\mathrm{t}-1}=\beta_{1}\left(1 / \mathrm{TA}_{\mathrm{t}-1}\right)+\beta_{2}\left(\Delta \mathrm{S}_{\mathrm{t}} / \mathrm{TA}_{\mathrm{t}-1}\right)+\beta_{3}\left(\Delta \mathrm{S}_{\mathrm{t}-1} / \mathbf{T A}_{\mathrm{t}-1}\right)+\varepsilon_{\mathrm{t}}$

Where:

$\Delta \mathrm{INV}_{\mathrm{t}}=$ the change in inventory in period $\mathrm{t}$.

Using the equations (2) and (3), the normal level of production costs is estimated as follows:

$\operatorname{PROD}_{\mathrm{t}} / \mathrm{TA}_{\mathrm{t}-1}=\beta_{1}\left(1 / \mathrm{TA}_{\mathrm{t}-1}\right)+\beta_{2}\left(\mathrm{~S}_{\mathrm{t}} / \mathrm{TA} A_{\mathrm{t}-1}\right)+\beta_{3}\left(\Delta \mathrm{S}_{\mathrm{t}} / \mathrm{TA}_{\mathrm{t}-1}\right)+\beta_{4}\left(\Delta \mathrm{S}_{\mathrm{t}-1} / \mathrm{TA} A_{\mathrm{t}-1}\right)$ 
For every firm-year, (APROD) is actual production cost minus normal production cost estimated from equation (4). A higher value of the residual (APROD) indicates increased manipulation through overproduction.

\subsubsection{Independent Variables}

Corporate governance mechanisms would be measured in table (1).

\subsubsection{Moderator Variable}

Ownership type is measured as (1) If the percentage of state ownership exceeds $50 \%$ (SOE), (0) otherwise (POE).

Table (1): Measurement of independent variables

\begin{tabular}{|l|l|}
\hline \multicolumn{1}{|c|}{ Independent variable } & \multicolumn{1}{|c|}{ Measurement } \\
\hline $\begin{array}{l}\text { Individual ownership } \\
\text { concentration } \\
\text { (INDCON) }\end{array}$ & $\begin{array}{l}\text { Total individual ownership of 5\% or more from the total } \\
\text { number of shares. }\end{array}$ \\
\hline $\begin{array}{l}\text { Managerial ownership } \\
\text { (MGOWN) }\end{array}$ & Percentage of shares owned by executive directors. \\
\hline Board size (BODSZ) & The number of members of the Board of Directors. \\
\hline $\begin{array}{l}\text { Board independence } \\
\text { (BODIND) }\end{array}$ & The proportion of non-executive directors on the board. \\
\hline CEO duality (DUAL) & $\begin{array}{l}\text { (1) If the CEO is the chairman of the board of directors, } \\
\text { (0) otherwise. }\end{array}$ \\
\hline $\begin{array}{l}\text { Audit committee size } \\
\text { (AUDSZ) }\end{array}$ & The number of audit committee members. \\
\hline $\begin{array}{l}\text { Audit committee } \\
\text { independence } \\
\text { (AUDIND) }\end{array}$ & $\begin{array}{l}\text { The proportion of non-executive members on the audit } \\
\text { committee. }\end{array}$ \\
\hline $\begin{array}{l}\text { Financial expertise of } \\
\text { audit committee } \\
\text { members (AUDEXP) }\end{array}$ & $\begin{array}{l}\text { The proportion of audit committee members with } \\
\text { accounting and financial qualification to the total number } \\
\text { of audit committee members. }\end{array}$ \\
\hline $\begin{array}{l}\text { Audit committee } \\
\text { meetings (No.meets.) }\end{array}$ & The number of audit committee meetings during the year. \\
\hline
\end{tabular}




\subsubsection{Substitution Control Variables}

Following prior studies (e.g. Zang (2012); and Alhadab and Nguyen (2018)), in order to control for the trade-off between different earnings management types, six control variables are added to the study models as follows:

Market share (Mktsh $\mathbf{i , t - 1}$ ), is used as a proxy for the level of competition. It is measured as the ratio of company's sales to total sales of its sector.

Institutional ownership (INST $\mathbf{i}, \mathbf{t}-1$ ), is measured as the percentage of outstanding shares owned by institutional investors.

Auditor scrutiny (Big $\mathbf{4}_{\mathrm{i}, \mathrm{t}}$ ), is used as a proxy for the auditor scrutiny. It is a dummy variable that equals (1) if the auditor is one of the big four audit firms and (0) otherwise.

Audit tenure (Audten $\mathbf{i , t}$ ), is used as another proxy for the auditor scrutiny. It is a dummy variable that equals (1) if a firm is audited by the same auditor for a period more than or equal to the sample median and (0) otherwise.

Length of operating cycle (OCycle $\mathbf{i}, \mathbf{t}-1)$, is used as a proxy for firms' accounting flexibility. It is measured as receivable turnover in days plus inventory turnover in days at the beginning of the year [365/ (Sales/Average Accounts Receivable) + 365/ (Cost of Goods Sold/Average Inventory)] .

Net operating assets $\left(\mathbf{N O A}_{i, t-1}\right)$, are used as a proxy for the extent of AEM in prior periods. It is measured as shareholders' equity less cash and marketable securities and total debt at the beginning of the year divided by total assets at the year beginning. 
Following Hunt et al. (1996) and Zang (2012), pre-managed earnings (PreEar.) is included in the REM model (equation 1) to control for manipulating earnings upwards.

\subsubsection{Firm characteristics control variables}

In accordance with most of prior earnings management studies, firm size $\left(F S Z E_{i, t}\right)$, firm performance $\left(\mathrm{ROA}_{\mathrm{i}, \mathrm{t}}\right)$, leverage $\left(\mathrm{LEV}_{\mathrm{i}, \mathrm{t}}\right)$, and firm growth $\left(\mathrm{GRW}_{\mathrm{i}, \mathrm{t}}\right)$ are added as corporate characteristics control variables to the study models.

\section{Empirical Results}

\subsection{Descriptive Statistics}

Table (2) presents descriptive statistics for the full sample of 743 firm-year observations. Approximately $32 \%$ of the sample firm-year observations are state-owned (239 observations) and the rest (504 observations) represent private sector companies. The descriptive statistics for the state-owned and privately-owned companies are shown in Tables (3) and (4), respectively. To avoid the influence of outliers, all continuous control variables are winsorized at the top 5\% and bottom $95 \%$ percentiles of their distribution.

The median of abnormal production cost (APROD) in the Egyptian manufacturing companies sample is $0.02 \%$ of total assets which is less than the $4 \%$ found by Cohen et al. (2008) in their USA sample and also less than the $1.3 \%$ reported by Kuo et al. (2014) in China. This implies that overproduction manipulation in Egypt is less severe than in other countries such as USA and China. The average percentage of abnormal production cost for state-owned manufacturing companies is $0.4 \%$ with a range between -74 
$\%$ and $41 \%$ of total assets, which is more than the privately-owned manufacturing companies, which is $-0.2 \%$ with a range between $-86 \%$ and $52 \%$ of total assets.

Regarding corporate governance mechanisms, descriptive statistics indicate that there is a high degree of compliance to the Egyptian corporate governance rules of the Audit Committees and the Board of Directors. However, the minimum zero values of both BODIND and AUDIND indicate the non-presence of independent directors on the board of directors and audit committee in some state-owned and privately-owned manufacturing companies. Also, there are a large number of manufacturing companies that do not comply with Egyptian Corporate Governance code regarding the separation between the position of chairman and chief executive officer position in the company; almost $70 \%$ of Egyptian manufacturing companies have duality. For the state-owned companies, $93 \%$ have duality while $59 \%$ of the private-sector companies have duality.

Table 2: Descriptive statistics for the full manufacturing sample

\begin{tabular}{|l|c|c|c|c|c|c|c|}
\hline Variable & Mean & Std. dev. & Min. & Max. & $\mathbf{2 5 \%}$ & $\mathbf{5 0 \%}$ & $\mathbf{7 5 \%}$ \\
\hline APROD & $\mathbf{0 . 0 0 0}$ & $\mathbf{0 . 1 0}$ & $\mathbf{- 0 . 8 6}$ & $\mathbf{0 . 5 2}$ & $\mathbf{- 0 . 0 5}$ & $\mathbf{0 . 0 0 0}$ & $\mathbf{0 . 0 5}$ \\
\hline INDCON & $\mathbf{0 . 0 9}$ & $\mathbf{0 . 1 8}$ & $\mathbf{0 . 0 0}$ & $\mathbf{0 . 9 0}$ & $\mathbf{0 . 0 0}$ & $\mathbf{0 . 0 0}$ & $\mathbf{0 . 1 0}$ \\
\hline MGOWN & $\mathbf{0 . 0 8}$ & $\mathbf{0 . 1 7}$ & $\mathbf{0 . 0 0}$ & $\mathbf{0 . 8 8}$ & $\mathbf{0 . 0 0}$ & $\mathbf{0 . 0 0}$ & $\mathbf{0 . 0 5}$ \\
\hline BODSZ & $\mathbf{7 . 7 9}$ & $\mathbf{2 . 7 0}$ & $\mathbf{1 . 0 0}$ & $\mathbf{1 7 . 0 0}$ & $\mathbf{5 . 0 0}$ & $\mathbf{7 . 0 0}$ & $\mathbf{9 . 0 0}$ \\
\hline BODIND & $\mathbf{0 . 6 5}$ & $\mathbf{0 . 2 3}$ & $\mathbf{0 . 0 0}$ & $\mathbf{1 . 0 0}$ & $\mathbf{0 . 5 0}$ & $\mathbf{0 . 7 3}$ & $\mathbf{0 . 8 3}$ \\
\hline AUDSZ & $\mathbf{3 . 4 6}$ & $\mathbf{1 . 0 1}$ & $\mathbf{0 . 0 0}$ & $\mathbf{8 . 0 0}$ & $\mathbf{3 . 0 0}$ & $\mathbf{3 . 0 0}$ & $\mathbf{4 . 0 0}$ \\
\hline AUDIND & $\mathbf{0 . 8 8}$ & $\mathbf{0 . 2 2}$ & $\mathbf{0 . 0 0}$ & $\mathbf{1 . 0 0}$ & $\mathbf{0 . 7 5}$ & $\mathbf{1 . 0 0}$ & $\mathbf{1 . 0 0}$ \\
\hline AUDEXP & $\mathbf{0 . 4 6}$ & $\mathbf{0 . 3 1}$ & $\mathbf{0 . 0 0}$ & $\mathbf{1 . 0 0}$ & $\mathbf{0 . 3 3}$ & $\mathbf{0 . 3 3}$ & $\mathbf{0 . 6 7}$ \\
\hline No. meets. & $\mathbf{5 . 2 5}$ & $\mathbf{3 . 8 3}$ & $\mathbf{0 . 0 0}$ & $\mathbf{4 0 . 0 0}$ & $\mathbf{4 . 0 0}$ & $\mathbf{4 . 0 0}$ & $\mathbf{4 . 0 0}$ \\
\hline Mktsh & $\mathbf{0 . 0 6}$ & $\mathbf{0 . 1 0}$ & $\mathbf{0 . 0 0}$ & $\mathbf{0 . 4 0}$ & $\mathbf{0 . 0 1}$ & $\mathbf{0 . 0 3}$ & $\mathbf{0 . 0 6}$ \\
\hline INST & $\mathbf{0 . 5 8}$ & $\mathbf{0 . 3 0}$ & $\mathbf{0 . 0 0}$ & $\mathbf{0 . 9 5}$ & $\mathbf{0 . 3 5}$ & $\mathbf{0 . 6 5}$ & $\mathbf{0 . 8 5}$ \\
\hline
\end{tabular}




\begin{tabular}{|l|c|c|c|c|c|c|c|}
\hline Logocycle & 2.15 & 0.35 & 1.37 & 2.74 & 1.96 & 2.19 & 2.42 \\
\hline NOA & 0.58 & 0.24 & 0.11 & 0.90 & 0.41 & 0.64 & 0.78 \\
\hline FSZE & 20.16 & 1.27 & 17.96 & 22.61 & 19.26 & 20.08 & $\mathbf{2 1 . 0 3}$ \\
\hline ROA & 0.07 & 0.10 & -0.11 & 0.28 & 0.01 & 0.06 & 0.13 \\
\hline LEV & 0.13 & 0.15 & 0.00 & 0.49 & 0.00 & 0.06 & 0.23 \\
\hline GRW & 1.65 & 0.96 & 0.21 & 3.51 & 0.89 & 1.56 & $\mathbf{2 . 3 5}$ \\
\hline PreEar. & 0.06 & 0.16 & -0.23 & 0.40 & $-\mathbf{0 . 0 5}$ & $\mathbf{0 . 0 5}$ & $\mathbf{0 . 1 6}$ \\
\hline
\end{tabular}

Dummy variables:

Dual (CEO-Chairman duality) $=1 ： \quad 70 \%$ Big4=1:33\% Audten=1: $53 \%$

Table 3: Descriptive statistics for the state-owned manufacturing firms

\begin{tabular}{|c|c|c|c|c|c|c|c|}
\hline Variable & Mean & Std. dev. & Min. & Max. & $25 \%$ & $50 \%$ & $75 \%$ \\
\hline APROD & 0.004 & 0.11 & -0.74 & 0.41 & -0.03 & 0.004 & 0.05 \\
\hline INDCON & 0.02 & 0.04 & 0.00 & 0.21 & 0.00 & 0.00 & 0.00 \\
\hline MGOWN & 0.01 & 0.03 & 0.00 & 0.21 & 0.00 & 0.00 & 0.00 \\
\hline BODSZ & 6.88 & 2.48 & 1.00 & 14.00 & 5.00 & 6.00 & 9.00 \\
\hline BODIND & 0.50 & 0.28 & 0.00 & 1.00 & 0.25 & 0.40 & 0.78 \\
\hline AUDSZ & 3.79 & 1.29 & 0.00 & 8.00 & 3.00 & 3.00 & 5.00 \\
\hline AUDIND & 0.79 & 0.30 & 0.00 & 1.00 & 0.67 & 1.00 & 1.00 \\
\hline AUDEXP & 0.59 & 0.27 & 0.00 & 1.00 & $\mathbf{0 . 3 3}$ & 0.67 & 0.75 \\
\hline No. meets. & 6.49 & 3.72 & 0.00 & 15.00 & 4.00 & 4.00 & 10.00 \\
\hline Mktsh & 0.09 & 0.12 & 0.00 & 0.40 & 0.02 & 0.04 & 0.08 \\
\hline INST & 0.77 & 0.14 & 0.49 & 0.95 & 0.67 & 0.74 & 0.92 \\
\hline Logocycle & 2.17 & 0.37 & 1.37 & 2.74 & 1.99 & 2.28 & 2.45 \\
\hline NOA & 0.45 & 0.23 & 0.11 & 0.90 & 0.27 & 0.45 & 0.62 \\
\hline FSZE & 20.47 & 1.14 & 17.96 & 22.61 & 19.59 & 20.14 & 21.33 \\
\hline ROA & 0.08 & 0.10 & -0.11 & 0.28 & 0.02 & 0.07 & 0.14 \\
\hline LEV & 0.09 & 0.14 & 0.00 & 0.49 & 0.00 & 0.01 & 0.14 \\
\hline GRW & 1.96 & 0.96 & 0.21 & 3.51 & 1.22 & 1.91 & 2.80 \\
\hline PreEar. & 0.07 & 0.16 & -0.23 & 0.40 & -0.04 & 0.06 & 0.16 \\
\hline
\end{tabular}

Dual (CEO-Chairman duality) =1: 93 \% Big 4= 1: $14 \%$ Audten=1: $79 \%$ 
Table 4: Descriptive statistics for the privately-owned manufacturing firms

\begin{tabular}{|c|c|c|c|c|c|c|c|}
\hline Variable & Mean & Std. dev. & Min. & Max. & $25 \%$ & $50 \%$ & $75 \%$ \\
\hline APROD & -0.002 & 0.10 & -0.86 & 0.52 & -0.06 & -0.001 & 0.04 \\
\hline INDCON & 0.13 & 0.21 & 0.00 & 0.90 & 0.00 & 0.00 & 0.21 \\
\hline MGOWN & 0.11 & 0.20 & 0.00 & 0.88 & 0.00 & 0.01 & 0.13 \\
\hline BODSZ & 8.22 & 2.70 & 3.00 & 17.00 & 6.00 & 8.00 & 10.00 \\
\hline BODIND & 0.73 & 0.16 & 0.00 & 1.00 & 0.63 & 0.78 & 0.86 \\
\hline AUDSZ & $\mathbf{3 . 3 0}$ & 0.80 & 0.00 & 7.00 & 3.00 & 3.00 & 3.00 \\
\hline AUDIND & 0.92 & 0.16 & 0.00 & 1.00 & 1.00 & 1.00 & 1.00 \\
\hline AUDEXP & 0.40 & 0.31 & 0.00 & 1.00 & 0.25 & $\mathbf{0 . 3 3}$ & 0.67 \\
\hline No. meets. & 4.66 & 3.74 & 0.00 & 40.00 & 4.00 & 4.00 & 4.00 \\
\hline Mktsh & 0.05 & 0.08 & 0.00 & 0.40 & 0.01 & 0.02 & 0.05 \\
\hline INST & 0.49 & 0.32 & 0.00 & 0.95 & 0.23 & 0.51 & 0.80 \\
\hline Logocycle & 2.15 & 0.35 & 1.37 & 2.74 & 1.95 & 2.15 & 2.38 \\
\hline NOA & 0.65 & 0.21 & 0.11 & 0.90 & 0.51 & 0.71 & 0.81 \\
\hline FSZE & 20.02 & 1.30 & 17.96 & 22.61 & 19.02 & 20.05 & 20.90 \\
\hline ROA & 0.07 & 0.09 & -0.11 & 0.28 & 0.01 & 0.05 & 0.12 \\
\hline LEV & 0.15 & 0.16 & 0.00 & 0.49 & 0.00 & 0.09 & 0.26 \\
\hline GRW & 1.50 & 0.92 & 0.21 & 3.51 & 0.76 & 1.40 & 2.16 \\
\hline PreEar. & 0.06 & 0.16 & -0.23 & 0.40 & -0.06 & 0.05 & 0.17 \\
\hline
\end{tabular}

Dual (CEO-Chairman duality) $=1: 59 \%$ Big 4=1: 42\%Audten $=1: 40 \%$

\subsection{Multiple Regression}

In order to test the research hypotheses concerning the effect of ownership type on the relationship between corporate governance mechanisms 
and overproduction. Clustered robust standard errors are used to correct for both heteroscedasticity and autocorrelation. Table 5 reports the results of multiple regression analysis for the model. The probability of $(\mathrm{F})$ value showed that the overall model is statistically significant at 0.01 levels. Adjusted $\mathrm{R}^{2}$ is $26.6 \%$. As observed from Table (5), the coefficient of ownership type (OWNT) is not statistically significant $(\beta=0.024$ and $\mathrm{P}$-value $=0.229)$. This is consistent with $H_{1}$ that predicts no relationship between overproduction and ownership type. Thus, $H_{l}$ cannot be rejected.

The results show that the board independence variable (BODIND) is significantly and negatively associated with abnormal production cost $(\beta=$ 0.0696 and P-value $=0.0001)$. Also, the ownership type interaction effect (OWNT* BODIND) is significant and positive $(\beta=+0.021$ and $\mathrm{P}$-value $=$ 0.0004). With respect to the magnitude, the coefficients on abnormal production cost are -0.0696 and $-0.0486(=-0.0696+0.021)$ for privatelyowned and state-owned, respectively. This significant moderation effect is contradictory to hypothesis 5 which predicts that the relationship between board independence and overproduction does not depend on ownership type. Therefore, $\mathrm{H}_{5}$ is rejected. This finding implies that the independent directors monitor the overproduction manipulation more effectively when the company is privately-owned and supports the doubts about the independence of board members in state-owned companies. This also is consistent with agency theory prediction that the independent board members are more effective in monitoring firm's managers and in restraining their opportunistic behavior (Fama and Jensen, 1983). Consistent with this finding, Visvanathan (2008) 
finds a negative relationship between board independence and overproduction manipulation.

With regard to board size (BODSZ), the results show a significant negative relationship between board size and abnormal production cost $(\beta=$ 0.002 and $\mathrm{P}$-value $=0.096)$ at $10 \%$ level of significance. The ownership type moderation effect $(\mathrm{OWNT} *$ BODSZ) is insignificant $(\mathrm{P}$-value $=0.274)$, which means that there is a negative relationship between board size and overproduction regardless of ownership type.

Table 5: Results of APROD model

\begin{tabular}{|c|c|c|}
\hline \multirow{2}{*}{ Variables } & \multicolumn{2}{|c|}{ APROD model } \\
\hline & Coeff. & Prob. \\
\hline OWNT & 0.0241 & 0.2296 \\
\hline INDCON & -0.0372 & 0.3703 \\
\hline MGOWN & $\mathbf{0 . 0 1 5 8}$ & 0.7136 \\
\hline BODSZ & -0.0021 & 0.0966 \\
\hline BODIND & -0.0696 & 0.0001 \\
\hline Dual & 0.0071 & 0.2832 \\
\hline AUDSZ & 0.0062 & 0.6024 \\
\hline AUDIND & -0.0107 & 0.5395 \\
\hline AUDEXP & $\mathbf{0 . 0 0 5 3}$ & 0.5964 \\
\hline No. meets. & -0.0018 & 0.0234 \\
\hline OWNT* INDCON & $\begin{array}{l}-0.0086 \\
\end{array}$ & 0.7295 \\
\hline OWNT* MGOWN & 0.0062 & 0.8418 \\
\hline OWNT* BODSZ & -0.0082 & 0.2704 \\
\hline OWNT* BODIND & 0.0210 & 0.0004 \\
\hline OWNT* Dual & -0.0227 & 0.2390 \\
\hline OWNT* AUDSZ & 0.0007 & 0.8794 \\
\hline OWNT* AUDIND & 0.0018 & 0.7327 \\
\hline OWNT* AUDEXP & -0.0216 & 0.0001 \\
\hline OWNT* No. meets. & -0.0011 & 0.8492 \\
\hline Mktsh & -0.0272 & 0.4567 \\
\hline INST & -0.0134 & 0.3490 \\
\hline Big 4 & 0.0051 & 0.4661 \\
\hline
\end{tabular}




\begin{tabular}{|l|r|r|} 
Audten & $\mathbf{0 . 0 0 4 7}$ & $\mathbf{0 . 4 2 0 4}$ \\
\hline OCycle & $\mathbf{0 . 0 0 8 6}$ & $\mathbf{0 . 3 6 2 1}$ \\
\hline NOA & $\mathbf{- 0 . 0 3 3 4}$ & $\mathbf{0 . 0 2 7 4}$ \\
\hline FSZE & $-\mathbf{0 . 0 0 0 1}$ & $\mathbf{0 . 9 8 5 5}$ \\
\hline ROA & $-\mathbf{0 . 1 3 1 4}$ & $\mathbf{0 . 0 0 0 1}$ \\
\hline LEV & $\mathbf{- 0 . 0 0 4 9}$ & $\mathbf{0 . 8 1 2 6}$ \\
\hline GRW & $\mathbf{0 . 0 0 0 6}$ & $\mathbf{0 . 8 7 1 8}$ \\
\hline PreEar & $\mathbf{- 0 . 2 9 5 9}$ & $\mathbf{0 . 0 0 0 0}$ \\
\hline N & \multicolumn{2}{|c|}{$\mathbf{7 4 3}$} \\
\hline R-squared & \multicolumn{2}{|c|}{$29.5 \%$} \\
\hline Adjusted R-squared & \multicolumn{2}{|c|}{$\mathbf{2 6 . 6 \%}$} \\
\hline F & \multicolumn{2}{|c|}{479.5} \\
\hline Prob. & \multicolumn{2}{|c|}{$\mathbf{0 . 0 0 0 0}$} \\
\hline
\end{tabular}

With regard to audit committee meetings (No. meets.), the results show a significant negative relationship between the number of audit committee meetings and abnormal production cost $(\beta=-0.0018$ and $\mathrm{P}$-value $=0.023)$. The ownership type moderation effect (OWNT* No. meets.) is insignificant $(\mathrm{P}$-value $=0.849)$, which means that there is a negative relationship between the number of audit committee meetings and overproduction regardless of ownership type. Accordingly, $H_{10}$ whichposits no effect for ownership type on the relationship between the number of audit committee meetings and overproduction cannot be rejected. This result implies that the meetings of the Audit Committee frequently enhance its effectiveness and therefore limits manipulation using production. This result is inconsistent with the result of Visvanathan (2008).

As for financial expertise for audit committee members (AUDEXP), the results indicate insignificant main effect on abnormal production cost $(\mathrm{P}$-value $=0.596)$ and a significant negative interaction effect for ownership type (OWNT* AUDEXP) $(\beta=-0.0216$ and P-value $=0.000)$. This result means 
that the ownership type moderates the relationship between financial expertise for audit committee members and abnormal production cost. Therefore, $H_{9}$ whichpredicts no relationship between financial expertise for audit committee members and overproduction regardless of ownership type is rejected. This result shows a negative relationship between financial expertise of audit committee members and overproduction manipulation in state-owned companies only. This result implies that the audit committee members with financial expertise in state-owned companies have the ability to restrain the overproduction manipulation. This finding contradicts the findings of Carcello et al. (2006) and Sun et al. (2014) that financial expertise for audit committee has insignificant effect on abnormal production cost.

Concerning the rest of corporate governance and ownership structure variables (ownership concentration, insider ownership, board characteristics, and audit committee characteristics), the results in Table (5) show no significant main relationship with abnormal production cost and also no significant moderation effect for ownership type which implies that the current corporate governance mechanisms are not effective in constraining overproduction practices. Therefore, it is obvious that all sub-hypotheses of overproduction cannot be rejected $\left(\mathrm{H}_{2} \& \mathrm{H}_{3} \& \mathrm{H}_{6} \& \mathrm{H}_{7} \& \mathrm{H}_{8}\right)$. The results indicate that the rest of corporate governance mechanisms (i.e. individual ownership concentration, insider ownership, separation between CEO and Chairman, audit committee size, audit committee independence) are all ineffective in constraining earnings management through production. These results confirm the argument that corporate governance mechanisms may not be effective in curbing real earnings management practices as they do for accrual earnings 
management. Consistent with this finding, Visvanathan (2008) finds that board size, separation between CEO and Chairman, audit committee size and audit committee independence are ineffective in constraining earnings management through production. Also, Sun et al. (2014) finds that board size, and audit committee size have insignificant relationship with overproduction manipulation.

As for the variables related to the constraints of real earnings management, the results show that both institutional ownership (INST) and market share (Mktsh) have no significant relationship with overproduction (Pvalue $=0.46$ and 0.35 , respectively). These findings suggest that the manipulation of earnings using production cost in Egyptian companies is not constrained by both institutional ownership and level of competition. This is contrary to the results found by Zhang (2012) in US, which suggest that the engagement of real earnings management is constrained by institutional ownership and the level of competition.

Regarding firm characteristic control variables, the results in Table (5) show company performance (ROA) is statistically significant and negative ( $\beta$ $=-0.131$ and $p$-value $=0.000$ ), which implies that Egyptian companies might be using overproduction to avoid reporting losses. Finally, the leverage (LEV), company growth (GRW) and firm size (FSZE) show insignificant relationships with overproduction.

\section{Conclusion}

This study investigates the effect of ownership type on the relation between corporate governance and overproduction. Abnormal production cost 
(APROD) is used as a proxy for overproduction. an empirical model is developed in which the Abnormal production cost represents the dependent variable. Independent variables are classified into four groups: first, ownership type variable. Second, corporate governance mechanisms, including individual ownership concentration, managerial ownership, board size, board independence, CEO duality, audit committee size, audit committee independence, number of meetings and financial expertise of audit committee members. Third, trade-off control variables, including market share, institutional ownership, auditor scrutiny, audit tenure, length of operating cycle, and net operating assets. Fourth, firm characteristics control variables, including firm size, firm performance, leverage and growth.

The APROD model is tested using a sample of manufacturing companies containing state-owned and privately-owned companies over the period from 2010 to 2017, with 743 firm-year observations. The results show insignificant relationship between state ownership and overproduction. The results show that board size, board independence, number of audit committee meetings, and financial expertise for audit committee members appear effective mechanisms for curbing manipulation using production costs in state-owned manufacturing companies. For privately-owned companies, the results reveal that board independence and number of audit committee meetings, appear effective mechanisms in constraining manipulation using production costs privately-owned manufacturing companies. 


\section{References}

Alhadab, M., \& Nguyen, T. (2018). Corporate diversification and accrual and real earnings management: A non-linear relationship. Review of Accounting and Finance, 17(2), 198-214.

Bushee, B. J. (1998). The influence of institutional investors on myopic R\&D investment behavior. Accounting review, 305-333.

Carcello, J. V., Hollingsworth, C. W., Klein, A., \& Neal, T. L. (2006). Audit committee financial expertise, competing corporate governance mechanisms, and earnings management. Competing Corporate Governance Mechanisms, and Earnings Management (February 2006).

Cohen, D. A., Dey, A., \& Lys, T. Z. (2008). Real and accrual-based earnings management in the pre-and post-Sarbanes-Oxley periods. The accounting review, 83(3), 757-787.

Degeorge, F., Patel, J., \& Zeckhauser, R. (1999). Earnings management to exceed thresholds. The Journal of Business, 72(1), 1-33.

Fama, E. F., \& Jensen, M. C. (1983). Separation of ownership and control. The journal of law and Economics, 26(2), 301-325.

Graham, J. R., Harvey, C. R., \& Rajgopal, S. (2005). The economic implications of corporate financial reporting. Journal of accounting and economics, 40(1-3), 3-73.

Hashemi, S. A., \& Rabiee, H. (2011). The role of corporate governance in real earnings management: evidence from Iran. Interdisciplinary Journal of Contemporary research in Business, 3(6), 848-858.

Healy, P. M., \& Wahlen, J. M. (1999). A review of the earnings management literature and its implications for standard setting. Accounting horizons, $13(4), 365-383$. 
Hsu, M. F., \& Wen, S. Y. (2015). The influence of corporate governance in Chinese companies on discretionary accruals and real earnings management. Asian Economic and Financial Review, 5(3), 391-406.

Hunt, A., Moyer, S. E., \& Shevlin, T. (1996). Managing interacting accounting measures to meet multiple objectives: A study of LIFO firms. Journal of Accounting and Economics, 21(3), 339-374.

Kang, S. A., \& Kim, Y. S. (2012). Effect of corporate governance on real activity-based earnings management: Evidence from Korea. Journal of Business Economics and Management, 13(1), 29-52.

Kang, S. A., \& Kim, Y. S. (2011). Does earnings management amplify the association between corporate governance and firm performance? Evidence from Korea. International Business \& Economics Research Journal, 10(2), 53-66.

Kuo, J. M., Ning, L., \& Song, X. (2014). The real and accrual-based earnings management behaviors: Evidence from the split share structure reform in China. The International Journal of Accounting, 49(1), 101-136.

Malik, M. (2011). Can Governance mitigate real earnings management? Available at SSRN 2256564.

Martinez, A. L. (2011). Do corporate governance special listing segments and auditing curb real and accrual-based earnings management? Evidence from Brazil. Revista Universo Contábil, 7(4), 98-117.

Roychowdhury, S. (2006). Earnings management through real activities manipulation. Journal of accounting and economics, 42(3), 335-370.

Sun, J., Lan, G., \& Liu, G. (2014). Independent audit committee characteristics and real earnings management. Managerial Auditing Journal, 29(2), 153172. 
Visvanathan, G. (2008). Corporate governance and real earnings management. Academy of Accounting and Financial Studies Journal, 12(1), 9-22.

Wu, L., \& Chen, K. C. (2006). State ownership and firm value in china. The International Journal of Finance 18 (1): 3821-3846.

Zang, A. Y. (2012). Evidence on the trade-off between real activities manipulation and accrual-based earnings management. The Accounting Review, 87(2), 675-703. 